Ambiente \& Água - An Interdisciplinary Journal of Applied Science
ISSN 1980-993X - doi:10.4136/1980-993X
www.ambi-agua.net
E-mail: ambi.agua@gmail.com

\title{
Variations in soil water replacement levels promote changes in forage cactus mineral composition and biomass productivity
}

\author{
ARTICLES doi:10.4136/ambi-agua.2537
}

Received: 01 Mar. 2020; Accepted: 28 Jul. 2020

\section{Rener Luciano de Souza Ferraz ${ }^{1 *}$; José Dantas Neto ${ }^{2}$; ${\text { Patrícia da Silva } \text { Costa }^{2} \text {; }}$; Antônio Suassuna de Lima ${ }^{2}$; Patrícia Ferreira da Silva ${ }^{2}$; Rigoberto Moreira de Matos ${ }^{2}$; ; Alberto Soares de Melo ${ }^{3}$}

\author{
${ }^{1}$ Departamento de Agroecologia e Agropecuária. Universidade Estadual da Paraíba (UEPB), Sítio Imbaúba, \\ s/n, CEP: 58.117-000, Lagoa Seca, PB, Brazil. \\ ${ }^{2}$ Centro de Tecnologia e Recursos Naturais (CTRN). Unidade Acadêmica de Engenharia Agrícola (UAEA). \\ Universidade Federal de Campina Grande (UFCG), Rua Aprígio Veloso, nº 882, CEP: 58429-900, \\ Campina Grande, PB, Brazil. E-mail: zedantas1955@gmail.com, patriciagroambiental@gmail.com, \\ suassunaagro@gmail.com, patrycyafs@yahoo.com.br, rigobertomoreira@gmail.com \\ ${ }^{3}$ Centro de Ciências Biológicas e da Saúde. Coordenação do Programa de Pós-Graduação em Ciências Agrárias. \\ Universidade Estadual da Paraíba (UEPB), Rua Domitila Cabral de Castro, s/n, CEP: 58.429-570, \\ Campina Grande, PB, Brazil. E-mail: albertosoares915@gmail.com \\ ${ }^{*}$ Corresponding author. E-mail: ferragroestat@gmail.com
}

\begin{abstract}
Population growth and the need to exploit natural resources to produce food and guarantee food sovereignty reduce water availability, which can influence nutrient absorption capacity and production of plants. This study evaluated whether variations in soil water replacement levels promote changes in the mineral composition and biomass productivity of forage cactus varieties. A field experiment was conducted in a randomized block design with five levels of reference evapotranspiration replacement $(25,50,75,100$ and $125 \%$ ETo $)$ and three replicates. Contents of the macronutrients $\mathrm{N}, \mathrm{P}, \mathrm{K}, \mathrm{Ca}, \mathrm{Mg}$ and $\mathrm{S}$; micronutrients $\mathrm{Cu}, \mathrm{Fe}, \mathrm{Mn}, \mathrm{Zn}, \mathrm{Cl}, \mathrm{Na}$ and $\mathrm{B}$; and biomass productivity were quantified in two varieties of forage cactus ('Orelha de Elefante Mexicana' and 'Miúda'). The data were subjected to principal component and multivariate variance analysis. The mineral composition of the forage cactus varieties 'Miúda' and 'Orelha de Elefante Mexicana' can be optimized from soil water management, so as to obtain adequate nutritional balance for higher yield. The replacement level of $75 \%$ ETo promoted greater balance between nutrients in the cladodes of the forage cactus variety 'Miúda', while 'Orelha de Elefante Mexicana' had better nutritional balance with the replacement levels of 100 and $125 \%$ ETo. Soil water replacement levels of 100 and $125 \%$ ETo promote high accumulation of $\mathrm{Na}^{+}$and $\mathrm{Cl}^{-}$ions in the cladodes of the forage cactus varieties studied. Highest biomass productivity of the varieties 'Orelha de Elefante Mexicana' and 'Miúda' was obtained with 75 and 100\% ETo replacement levels, respectively. Among the varieties, 'Orelha de Elefante Mexicana' had a higher capacity for nutrient accumulation and biomass productivity, followed by 'Miúda', under the edaphoclimatic conditions of the Brazilian semiarid region.
\end{abstract}

Keywords: irrigation, mineral nutrition, Nopalea, Opuntia, water requirement.

This is an Open Access article distributed under the terms of the Creative Commons Attribution License, which permits unrestricted use, distribution, and reproduction in any medium, provided the original work is properly cited. 


\section{Variações nos níveis de reposição hídrica no solo promovem mudanças na composição mineral e produtividade de biomassa de palma forrageira}

\section{RESUMO}

O aumento populacional e necessidade de exploração de recursos naturais para produção de alimentos e garantia da soberania alimentar reduzem a disponibilidade hídrica e isso pode influenciar a capacidade de absorção de nutrientes e produção das plantas. Objetivou-se avaliar se as variações nos níveis de reposição hídrica no solo promoveram mudanças na composição mineral e produtividade de biomassa de variedades de palma forrageira. Foi instalado experimento de campo em delineamento de blocos casualizados com cinco níveis de reposição da evapotranspiração de referência $(25,50,75,100$ e $125 \%$ da ETo) e três repetições. Em duas variedades de palma forrageira (Miúda e Orelha de Elefante Mexicana) foram quantificados os teores dos macronutrientes, N, P, K, Ca, Mg e S; dos micronutrientes $\mathrm{Cu}, \mathrm{Fe}, \mathrm{Mn}, \mathrm{Zn}, \mathrm{Cl}, \mathrm{Na}$ e $\mathrm{B}$; e produtividade de biomassa. Os dados foram submetidos à análise de componentes principais e variância multivariada. A composição mineral das variedades de palma forrageira 'Miúda' e 'Orelha de Elefante Mexicana' pode ser otimizada a partir do manejo de água no solo, de modo a ser obter balanço nutricional adequado para maior produtividade. O nível de reposição de $75 \%$ da $\mathrm{ET}_{\mathrm{o}}$ proporcionou maior equilíbrio entre os nutrientes nos cladódios da variedade de palma forrageira 'Miúda', já a variedade 'Orelha de Elefante Mexicana' teve melhor balanço nutricional com os níveis de reposição de 100 e $125 \%$ da ETo. Os níveis de reposição de água no solo de 100 e $125 \%$ da ETo promovem elevado acúmulo de íons $\mathrm{Na}^{+}$e $\mathrm{Cl}^{-}$nos cladódios das variedades de palma forrageira estudadas. Maior produtividade de biomassa das variedades 'Orelha de Elefante Mexicana' e 'Miúda' foi obtida com reposições 75 e $100 \%$ da ETo, respectivamente. Dentre as variedades, a 'Orelha de Elefante Mexicana' teve maior capacidade de acúmulo de nutrientes e produtividade de biomassa, seguida da 'Miúda' nas condições edafoclimáticas do semiárido brasileiro.

Palavras-chave: demanda hídrica, irrigação, Nopalea, nutrição mineral, Opuntia.

\section{INTRODUCTION}

Growing water scarcity can be defined as the imbalance between high demand due to population growth and economic development and low availability of water that can occur due to the effects of climate change (Santana et al., 2019; Benites-Lazaro et al., 2020). The Brazilian semiarid region undergoes constant changes in land use due to deforestation and high seasonality of water, represented among other variables by the decline in soil moisture content (Queiroz et al., 2020; Santos et al., 2020).

Soil moisture content is a vital component of the hydrological cycle, with a strong effect on the dynamics of carbon, water and energy at the surface-atmosphere interface. This is a determining factor in the patterns of plant distribution and growth in arid and semiarid environments (Medeiros et al., 2020). Indeed, soil moisture maintenance acts in the dynamics of microorganisms that are fundamental for nutrient cycling and fertility of agroecosystems, which stimulates plant growth and production (Zhou et al., 2020).

All this information highlights the importance of strategies of coexistence with the edaphoclimatic characteristics of the semiarid region. Thus, the cultivation of adapted plants is an efficient alternative for production in limiting environments. Cactus species (e.g. Nopalea ssp. and Opuntia ssp.) have anatomical and morphophysiological characteristics that favor their adaptation to the environmental conditions in these regions (Cardoso et al., 2019). 
Forage cactus is a plant with CAM (Crassulacean Acid Metabolism), a photosynthetic adaptation that facilitates the absorption of carbon dioxide at night, hence increasing water use efficiency, which enables crops to grow in arid and semiarid climates and, at the same time, produce aboveground biomass comparable to $\mathrm{C}_{3}$ and $\mathrm{C}_{4}$ crops with only $20 \%$ of water needs (Krümpel et al., 2020).

In Brazil, it is estimated that currently there are approximately 600,000 hectares cultivated with Opuntia ficus-indica (L.) Mill. and Nopalea cochenillifera (L.) Salm-Dyck (Cardoso et al., 2019). Opuntia is a drought-tolerant cactus, widely cultivated in semiarid and arid regions and has fruits and cladodes that can be used as sources of nutrients and phytochemicals (Salehi et al., 2019; Liguori et al., 2020). Nopalea stands out for having nutritional qualities and resistance to cochineal (Cardoso et al., 2019).

Forage cactus plays a supplemental role in the feeding of herds during the dry season (Rezende et al., 2020). However, studies indicate that adequate management, fertilization and irrigation are necessary for the satisfactory increase in its yield, so that the crop can express its best production potential, especially in regions with high seasonality of production and irregularity of rains such as the semiarid region (Silva et al., 2019).

In a systematic review and meta-analysis study, Ferraz et al. (2019) found that irrigated forage cactus crops promote yield increment of $53.54 \mathrm{t} \mathrm{ha}^{-1}$ year $^{-1}$ when compared to rainfed crops, with possible yields of $80.25 \mathrm{t} \mathrm{ha}^{-1}$ year $^{-1}$ under high irrigation depths and $26.83 \mathrm{tha}^{-1}$ year $^{-1}$ with lower irrigation depths in environments with higher rainfall. However, the significant increase in yield may result in a reduction in nutrient contents in forage cactus.

In irrigated forage cactus cultivation systems with high yield, it is essential to monitor the mineral composition of cladodes, because the increase in biomass can generate a nutrient dilution effect and compromise the nutritional quality of this feed for herds, since Nopalea ssp. and Opuntia ssp. provide food and water for animals and reductions in nutritional contents can influence the production and quality of meat (Moura et al., 2020). In this context, this study evaluated whether variations in soil water replacement levels promote changes in the mineral composition and biomass productivity of forage cactus varieties.

\section{MATERIAL AND METHODS}

\subsection{Experimental area location and characterization}

The experiment was conducted between May 2015 and December 2016, under field conditions, on the Poço Redondo farm, municipality of Santa Luzia, Seridó Ocidental Paraibano microregion, latitude of $06^{\circ} 52^{\prime} 27^{\prime}$ ' S, longitude of $36^{\circ} 56^{\prime} 00^{\prime}$ ' W Gr, and altitude of $299 \mathrm{~m}$.

The climate of the region is Bsh-Tropical, hot-dry semiarid with summer rains, according to Köppen's classification (Köppen and Geiger, 1928). Annually, the average precipitation of the region is $500 \mathrm{~mm}$, with a minimum temperature of $22.3^{\circ} \mathrm{C}$, average temperature of $27.6^{\circ} \mathrm{C}$, maximum temperature of $33.0^{\circ} \mathrm{C}$ and relative humidity ranging from 50 to $70 \%$. During the experiment, meteorological variables were monitored and expressed in climograph (Figure 1).

The soil of the experimental area was classified according to texture as sandy loam. For this, single samples were collected at depths of 0-0.20 m and 0.20-0.40 m, homogenized, placed in plastic bags and transported to the Irrigation and Salinity Laboratory (LIS) of the Center for Technology and Natural Resources (CTRN) of the Federal University of Campina Grande (UFCG) for chemical and physical-hydraulic characterization (Tables 1 and 2).

The water used for irrigation during the experiment was monitored for its chemical composition. For this, water samples from a shallow well (Amazonas type) located $80 \mathrm{~m}$ away from the experimental area were collected every three months. The samples were transported to LIS/CTRN/UFCG, and the following average data of chemical composition of the water were obtained: $\mathrm{pH}=7.48, \mathrm{Ca}=2.21 \mathrm{meq} \mathrm{L}^{-1}, \mathrm{Mg}=2.98 \mathrm{meq} \mathrm{L}^{-1}, \mathrm{Na}=8.44 \mathrm{meq} \mathrm{L}^{-1}, \mathrm{~K}=0.56$ 
meq $\mathrm{L}^{-1}, \mathrm{CO}_{3}=0.64$ meq $\mathrm{L}^{-1}, \mathrm{HCO}_{3}=3.25 \mathrm{meq} \mathrm{L}{ }^{-1}, \mathrm{Cl}=11.47 \mathrm{meq} \mathrm{L}{ }^{-1}$, sulfates $=$ present, sodium adsorption ratio $-\mathrm{SAR}=5.24 \mathrm{meq} \mathrm{L}^{-1}$ and electrical conductivity $-\mathrm{ECw}=1.37 \mathrm{dS} \mathrm{m}^{-}$ 1 , being classified as $\mathrm{C}_{3} \mathrm{~S}_{1}$, according to the classification of the United States Salinity Laboratory -USSL.

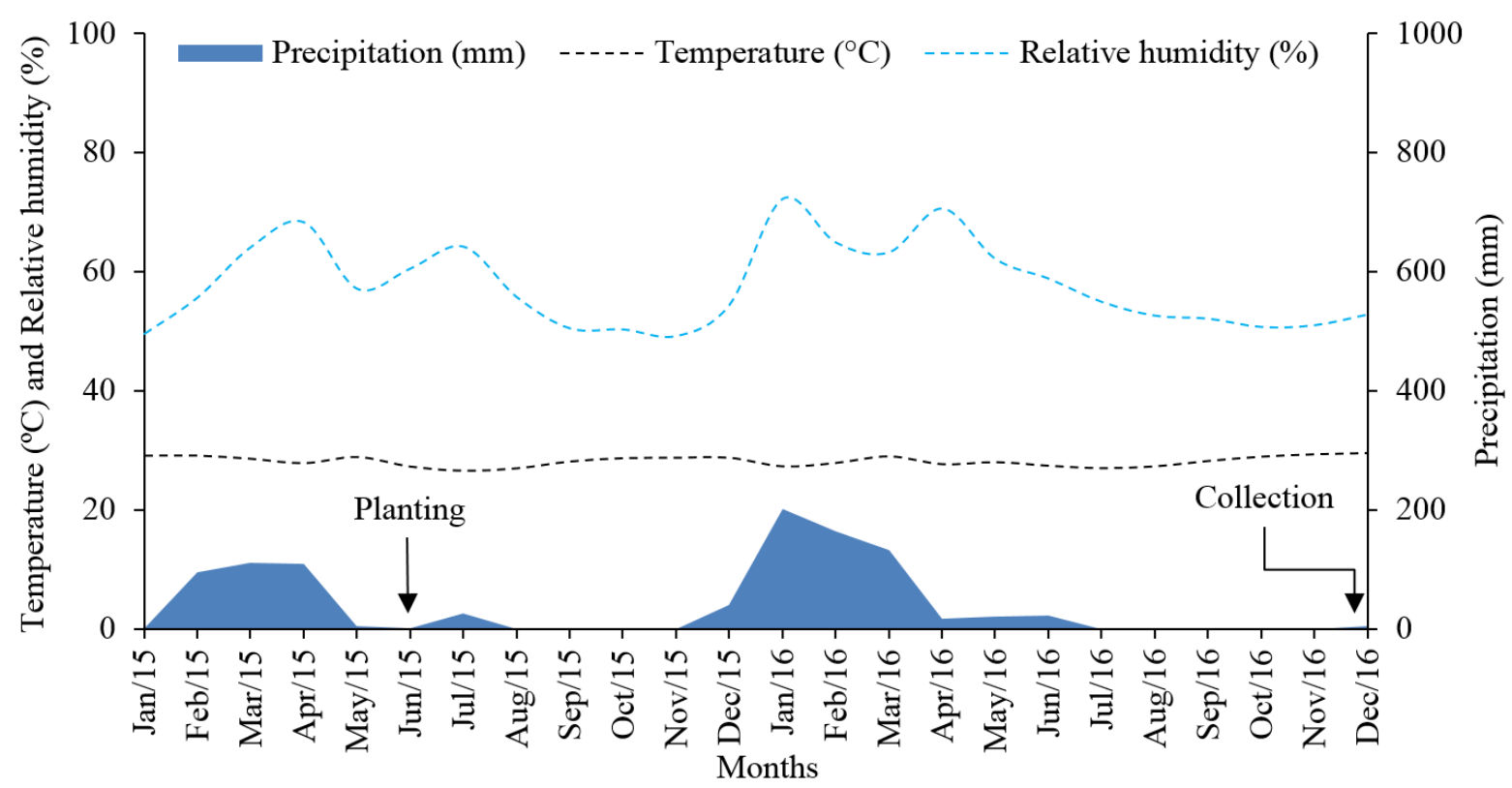

Figure 1. Climograph with the meteorological variables recorded during the experimental period.

Table 1. Chemical characterization of the sorption complex and saturation extract of the soil of the experimental area at two depths.

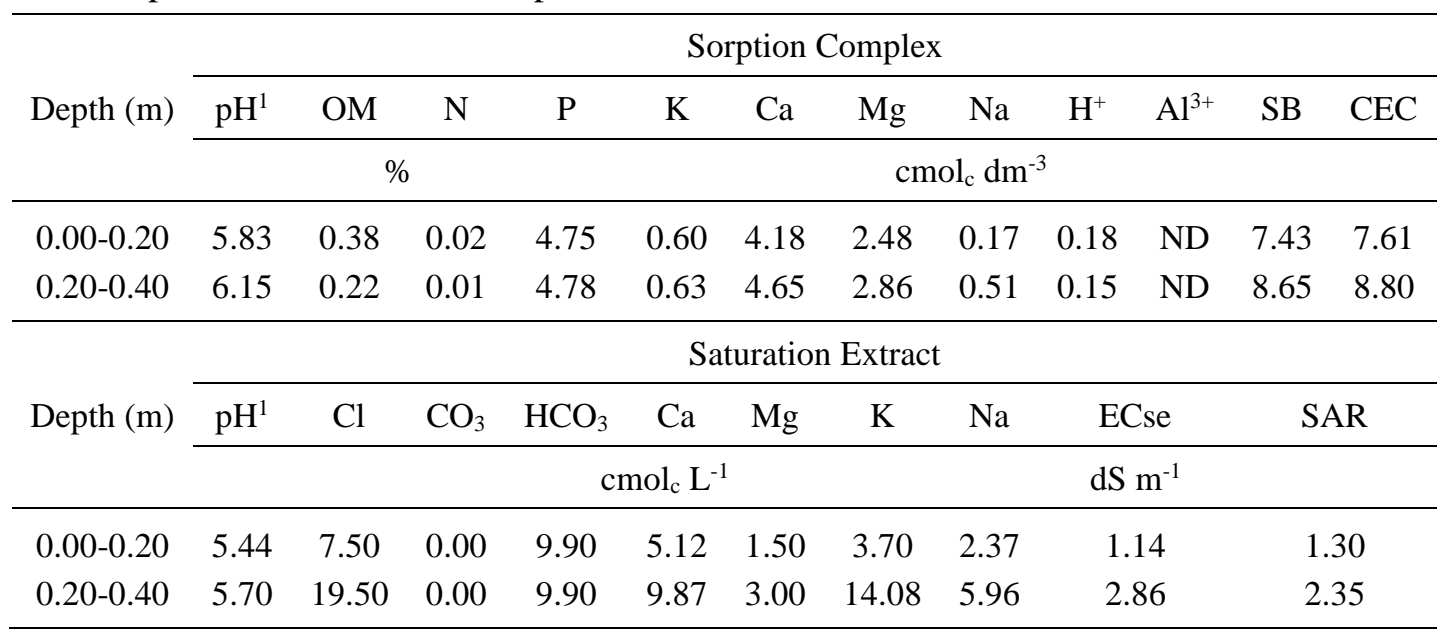

${ }^{1}: \mathrm{pH}$ in water; OM: organic matter; $\mathrm{SB}$ : sum of bases; CEC: cation exchange capacity; ECse: electrical conductivity of the soil saturation extract; SAR: sodium adsorption ratio; and ND: not detected.

Table 2. Physical-hydraulic characterization of the soil of the experimental area at two depths.

\begin{tabular}{|c|c|c|c|c|c|c|c|c|c|c|c|c|c|}
\hline \multirow{2}{*}{ Depth (m) } & Sand & Silt & Clay & $\mathrm{n}$ & $\mathrm{BD}$ & PD & $\mathrm{U}-0.1$ & U-0.3 & $\mathrm{U}-1.0$ & $\mathrm{U}-5.0$ & $\mathrm{U}-10.0$ & U-15.0 & AW \\
\hline & \multicolumn{4}{|c|}{$\%$} & \multicolumn{2}{|c|}{$\mathrm{g} \mathrm{cm}^{-3}$} & \multicolumn{7}{|c|}{$\%$} \\
\hline $0.00-0.20$ & 74.83 & 17.28 & 7.89 & 44.23 & 1.47 & 1.39 & 18.56 & 12.10 & 9.34 & 5.15 & 4.88 & 4.44 & 7.66 \\
\hline $0.20-0.40$ & 67.71 & 18.30 & 13.99 & 46.48 & 1.39 & 2.60 & 20.14 & 14.79 & 10.28 & 6.29 & 6.01 & 5.39 & 9.40 \\
\hline
\end{tabular}

n: porosity, BD: bulk density, PD: particle density, U: soil moisture between 0.1 and 15 atmosphere; AW: available water in the soil. 


\subsection{Experimental design}

The experiment was installed in a randomized block design and the treatments consisted of five levels of reference evapotranspiration replacement $(25,50,75,100$ and 125\% ETo) with three replicates (blocks), using two varieties of forage cactus - MI = Miúda (Nopalea cochenillifera Salm - Dyck) and - OR = Orelha de Elefante Mexicana (Opuntia ficus-indica (L.) Mill.). Each plot had an area of $14.4 \mathrm{~m}^{2}$, consisting of a double row with spacing of $0.4 \mathrm{~m}$ between rows, $2.0 \mathrm{~m}$ between double rows and $0.25 \mathrm{~m}$ between plants, with length of $5 \mathrm{~m}$ and border of $1 \mathrm{~m}$, adopting a usable area of $0.6 \mathrm{~m}^{2}$ in the plot.

From soil fertility analysis, organic fertilization was performed with $1.0 \mathrm{~kg}$ of bovine manure per linear meter. Following the recommendation of Santos et al. (2006), phosphate fertilization was also performed with $100 \mathrm{~kg} \mathrm{ha}^{-1}$ of $\mathrm{P}_{2} \mathrm{O}_{5}$ and potassium fertilization with 65 $\mathrm{kg} \mathrm{ha}^{-1}$ of $\mathrm{K}_{2} \mathrm{O}$, using $200 \mathrm{~kg} \mathrm{ha}^{-1}$ monoammonium phosphate (MAP) and $108.33 \mathrm{~kg} \mathrm{ha}^{-1}$ of potassium chloride $(\mathrm{KCl})$ as sources of these nutrients. Nitrogen fertilization was performed using $900 \mathrm{~kg} \mathrm{ha}^{-1}$ nitrogen $(\mathrm{N})$, applying 2,000 $\mathrm{kg} \mathrm{ha}^{-1}$ of urea as a source of $\mathrm{N}$, supplied via monthly fertigation, split and applied over 18 months.

\subsection{Vegetative propagules and planting}

The vegetative propagules (cladodes) were obtained from rural producers in the municipality of Santarém, PB, in partnership with the National Institute of the Semiarid Region (INSA). This material was selected by opting for uniform cladodes that were free of pests and diseases. After screening, the cladodes were kept in an open environment with reduced lighting for seven days, for partial dehydration and healing of the lesions caused by the cutting. The cladodes were planted on May 29, 2015, by placing the propagative material in the planting furrows, with the cladode facing the sunrise, at a $45^{\circ}$ angle, and $50 \%$ of the cladode buried in the soil in a bilateral alignment.

\subsection{Application of treatments and cultivation practices}

ETo levels were replaced using a localized drip irrigation system, consisting of a drip tube with a wall thickness of $0.2 \mathrm{~mm}$, internal diameter of $16 \mathrm{~mm}$, spacing between drippers of 0.20 $\mathrm{m}$; nominal pressure of $68.6 \mathrm{kPa}$; flow rate of $6.0 \mathrm{~L} \mathrm{~h}^{-1} \mathrm{~m}^{-1}$. The emitter equation was $\mathrm{q}=0.46$ $\mathrm{x} \mathrm{p}^{0.5}$, and the application efficiency of the system was 0.96 .

The irrigation system was pressurized using a 3-HP centrifugal motor-pump set. A 2" disc filter was used in the discharge piping, and Bourdon-type manometers tested and calibrated before irrigations were used in the lateral lines. At the beginning of the experimental area, a hydrometer was installed to monitor the amount of water applied during the experimental period.

For each ETo replacement level, the following components were quantified: net irrigation depth $\left(\mathrm{D}_{\mathrm{NET}}\right)$, in $\mathrm{mm}$, taking into account the fraction applied in each plot $\left(\mathrm{D}_{\mathrm{AP}}\right)$, decimal, and the effective precipitation in the period $(\mathrm{P})$, in mm, obtained using the expression: $D_{N E T}=(E T o$ * $\left.D_{A P}\right)$ - $P$. The gross irrigation depth (D $\mathrm{D}_{\mathrm{GROSS}}$ ) was calculated based on the system's efficiency of application (Ea), in decimal, using the expression: $D_{G R O S S}=D_{N E T} / E a$. The volumes applied by irrigation in each treatment corresponded to $111.32,222.65,333.98,445.31$ and $556.64 \mathrm{~mm}$, which added to the precipitation during the period, reached 578.22, 689.55, 800.88, 912.21 and $1,023.54 \mathrm{~mm}$.

The irrigation system's intensity of application (Ia), in $\mathrm{mm} \mathrm{h}^{-1}$, was calculated considering: number of emitters $(\mathrm{Ne})$ - two per plant; flow rate - $1.21 \mathrm{~L} \mathrm{~h}^{-1}$; and area occupied by the plant (A) $-0.30 \mathrm{~m}^{2}$, using the expression: $I a=(N e * q) / A$. The irrigation time (Ti) required for ETo replacement in each treatment was calculated based on the gross irrigation depth (DGRoss) in $\mathrm{mm}$; and the irrigation system's intensity of application (Ia), in $\mathrm{mm} \mathrm{h}^{-1}$, using the expression: $T i=D_{\text {GROSS }} / I a$. 


\subsection{Analysis of cladode mineral composition and biomass productivity}

At 540 days after planting (DAP), three cladodes were collected from different plants in the usable area of each plot, standardized by weight, size, development stage and position on the plant. The samples were weighed to obtain the fresh mass (g) and taken to the Irrigation and Drainage Engineering Laboratory (LEID) of CTRN/UFCG, where they were cut into pieces, placed in previously identified paper bags and dried in a forced air circulation oven at $60^{\circ} \mathrm{C}$ until they reached constant weight. Subsequently, the material was weighed, crushed, sieved using 1.0-mm-mesh sieves and stored in hermetically sealed containers.

The containers with the samples were transported to the Laboratory of Soil Chemistry and Fertility of the Center for Agrarian Sciences (CCA) of the Federal University of Paraíba (UFPB) for the analysis of mineral composition, expressed through the contents of macronutrients, N, $\mathrm{P}, \mathrm{K}, \mathrm{Ca}, \mathrm{Mg}$ and $\mathrm{S}$, and micronutrients, $\mathrm{Cu}, \mathrm{Fe}, \mathrm{Mn}, \mathrm{Zn}, \mathrm{Cl}, \mathrm{Na}$ and $\mathrm{B}$, using the methodology of Embrapa (2009).

To evaluate biomass productivity (BP), the cladodes subsequent to the basal cladode of the usable area of each plot were cut and weighed on a scale with precision of \pm 0.01 . Productivity $\left(\mathrm{t} \mathrm{ha}^{-1}\right)$ was estimated by multiplying the average mass of cladodes by the average number of cladodes per plant and by the number of plants per hectare.

\subsection{Statistical analysis}

The data were normalized for zero mean $(\bar{X}=0.0)$ and unit variance $\left(\sigma^{2}=1.0\right)$. The multivariate structure of the results was evaluated using the exploratory Principal Component Analysis (PCA), condensing the amount of relevant information contained in the original data set in a smaller number of dimensions, resulting from linear combinations of the original variables generated from the highest eigenvalues $(\lambda>1.0)$ in the correlation matrix, explaining a percentage greater than $10 \%$ of $\sigma^{2}$ (Govaerts et al., 2007).

Only variables with Pearson's correlation coefficient above 0.5 were maintained in the composition of each Principal Component (PC) (Hair Jr. et al., 2009). Correlations were classified according to Dancey and Reidy (2013) as weak $(r=0.10-0.30)$, moderate $(r=0.40$ 0.60 and strong $(r=0.70-1.00)$. Variables not associated with PCs $(r<0.5)$ were removed from the normalized database and a new analysis was performed. Four variables were removed and 10 were considered for the variety 'Miúda' and two variables were removed and 12 were considered for the variety 'Orelha de Elefante Mexicana'.

Variables on each PC were submitted to multivariate analysis of variance (MANOVA) by Hotelling's test $(\mathrm{P}<0.05)$. Not associated original variables data with $\mathrm{PCs}$ were submitted to univariate analysis of variance (ANOVA) by F test $(\mathrm{P}<0.05)$ and means were compared using the Tukey test, as the regression deviations were significant. Varieties were not compared because they are different species. The analyses were carried out using Statistica software v. 7.0 .

\section{RESULTS AND DISCUSSION}

In the forage cactus 'Miúda', the contents of macro and micronutrients were correlated in two dimensions $\left(\mathrm{PC}_{1}\right.$ and $\left.\mathrm{PC}_{2}\right)$, which represent $90.53 \%$ of the total experimental variance. $\mathrm{PC}_{1}$ accounts for $60.72 \%$ of the total variance, formed from the linear combination between the contents of $\mathrm{N}, \mathrm{P}, \mathrm{K}, \mathrm{Mg}, \mathrm{Cl}, \mathrm{B}, \mathrm{Fe}$ and $\mathrm{Mn}$; and $\mathrm{PC}_{2}$ represents $29.81 \%$ of the remaining variance, formed from the contents of $\mathrm{Na}$ and $\mathrm{Cu}$ (Table 3). $\mathrm{Ca}, \mathrm{S}, \mathrm{Zn}$ contents and $\mathrm{BP}$ were not related in $\mathrm{PC}_{1}$ and $\mathrm{PC}_{2}$. The results of PCA and absolute contents of macro and micronutrients of 'Miúda' forage cactus obtained at each level of ETo replacement are presented in Table 3. 
Table 3. Eigenvalues, variance, coefficients of correlation between Principal Components and variables and means of treatments for the forage cactus variety 'Miúda'.

\begin{tabular}{|c|c|c|c|c|c|c|c|c|c|c|c|c|c|c|c|c|c|}
\hline \multirow{2}{*}{ PCs } & \multirow{2}{*}{$\lambda$} & \multirow{2}{*}{$\sigma^{2 \%}$} & \multirow{2}{*}{$P$} & \multicolumn{14}{|c|}{ Factorial Loadings (r) } \\
\hline & & & & $\mathrm{N}^{1}$ & $\mathrm{P}^{1}$ & $\mathrm{~K}^{1}$ & $\mathrm{Ca}^{1}$ & $\mathrm{Mg}^{1}$ & $\mathrm{Na}^{1}$ & $\mathrm{Cl}^{1}$ & $S^{2}$ & $\mathrm{~B}^{2}$ & $\mathrm{Cu}^{2}$ & $\mathrm{Zn}^{2}$ & $\mathrm{Fe}^{2}$ & $\mathrm{Mn}^{2}$ & $\mathrm{BP}^{3}$ \\
\hline $\mathrm{PC}_{1}$ & 6.07 & 60.72 & $<0.001$ & $-0.84^{*}$ & $-0.86^{*}$ & $-0.92^{*}$ & $\mathrm{R}$ & $-0.78^{*}$ & 0.05 & $-0.96^{*}$ & $\mathrm{R}$ & $-0.95^{*}$ & -0.31 & $\mathrm{R}$ & $-0.73^{*}$ & $-0.84^{*}$ & $\mathrm{R}$ \\
\hline \multirow[t]{7}{*}{$\mathrm{PC}_{2}$} & 2.98 & 29.81 & $<0.001$ & 0.28 & 0.48 & 0.37 & $\mathrm{R}$ & -0.59 & $-0.96^{*}$ & -0.22 & $\mathrm{R}$ & 0.01 & $-0.86^{*}$ & $\mathrm{R}$ & 0.46 & -0.52 & $\mathrm{R}$ \\
\hline & ETo & & & & & & & & & & leans & & & & & & \\
\hline & $25 \%$ & & & 14.18 & 0.14 & 11.68 & 4.46 & 13.54 & 2.64 & 32.86 & 75.38 & 66.41 & 5.58 & 18.07 & 49.07 & 348.60 & 204.16 \\
\hline & $50 \%$ & & & 17.35 & 0.20 & 18.48 & 3.47 & 14.04 & 2.26 & 41.34 & 94.73 & 69.81 & 6.16 & 18.00 & 133.44 & 434.45 & 130.55 \\
\hline & $75 \%$ & & & 21.35 & 0.23 & 34.73 & 4.46 & 18.47 & 1.88 & 60.42 & 67.12 & 97.02 & 8.64 & 18.64 & 148.51 & 746.21 & 91.67 \\
\hline & $100 \%$ & & & 23.10 & 0.20 & 26.16 & 4.14 & 22.00 & 3.28 & 64.66 & 67.63 & 86.25 & 9.64 & 29.12 & 104.15 & 747.81 & 241.66 \\
\hline & $125 \%$ & & & 14.88 & 0.17 & 16.37 & 4.46 & 20.40 & 3.67 & 53.00 & 86.99 & 80.58 & 18.44 & 15.22 & 95.22 & 814.67 & 125.00 \\
\hline
\end{tabular}

PCs: principal components; $\lambda$ : eigenvalues; $\sigma^{2} \%$ : portion of the variance explained; 1 : means in $\mathrm{g} \mathrm{kg}^{-1} ; 2$ : means in $\mathrm{mg} \mathrm{kg}^{-1} ; 3: \mathrm{means}$ in $\mathrm{t} \mathrm{ha}{ }^{-1}$; ETo: reference evapotranspiration; R: variable removed from principal component analysis; P: probability of the significance test by Hotelling's test; and

*: variables considered in the PC; $r=0.10-0.30$ (weak correlation); $r=0.40-0.60$ (moderate correlation); $r=0.70-1.00$ (strong correlation).

Regardless of the ETo replacement level, the order of magnitude of macronutrient accumulation in cladodes of 'Miúda' forage cactus, in g $\mathrm{kg}^{-1}$, was: $\mathrm{Ca}(41.94 \pm 3.84)>\mathrm{K}(21.48 \pm 8.11)>\mathrm{N}(18.17 \pm 3.52)>\mathrm{Mg}(17.69 \pm 3.38)>\mathrm{P}(1.90 \pm 0.31)>\mathrm{S}(0.08 \pm 0.01)$; and for micronutrients, in $\mathrm{mg} \mathrm{kg}{ }^{-1}$, the order was: $\mathrm{Cl}(50456.00 \pm 11834.08)>\mathrm{Na}(2746.00 \pm 65365)>\mathrm{Mn}(618.35 \pm 188.80)>\mathrm{Fe}(108.08 \pm 34.41)>\mathrm{B}(80.01 \pm 11.11)>\mathrm{Zn}$ $(19.81 \pm 4.80)>\mathrm{Cu}(9.69 \pm 4.63)$.

In $\mathrm{PC}_{1}$, it was found that the forage cactus 'Miúda' has higher relative accumulation of N, P, K, B and Fe under replacement of $75 \%$ ETo, whereas relative contents of $\mathrm{Cl}, \mathrm{Mg}$ and $\mathrm{Mn}$ are accumulated in greater quantity with $100 \%$ ETo replacement. It should be emphasized that lower accumulation of these nutrients was observed with $25 \%$ ETo replacement. $\mathrm{In}_{\mathrm{PC}}$, it was found that the forage cactus 'Miúda' accumulates higher contents of $\mathrm{Na}$ and $\mathrm{Cu}$ when $125 \%$ of ETo is replaced, while lower contents of these nutrients were found with 50\% ETo (Figure 2 A and B).

$\mathrm{Ca}$ contents were reduced when the forage cactus 'Miúda' was irrigated with 50\% ETo replacement, whereas the other levels did not cause differences (Figure 2 C). S contents did not differ with variation in ETo levels (Figure 2 D). Replacement of 100\% ETo increased Zn contents in the cladodes (Figure 2 E). Irrigation with 25 or $100 \%$ ETo promoted higher biomass productivity (Figure $2 \mathrm{~F}$ ). 

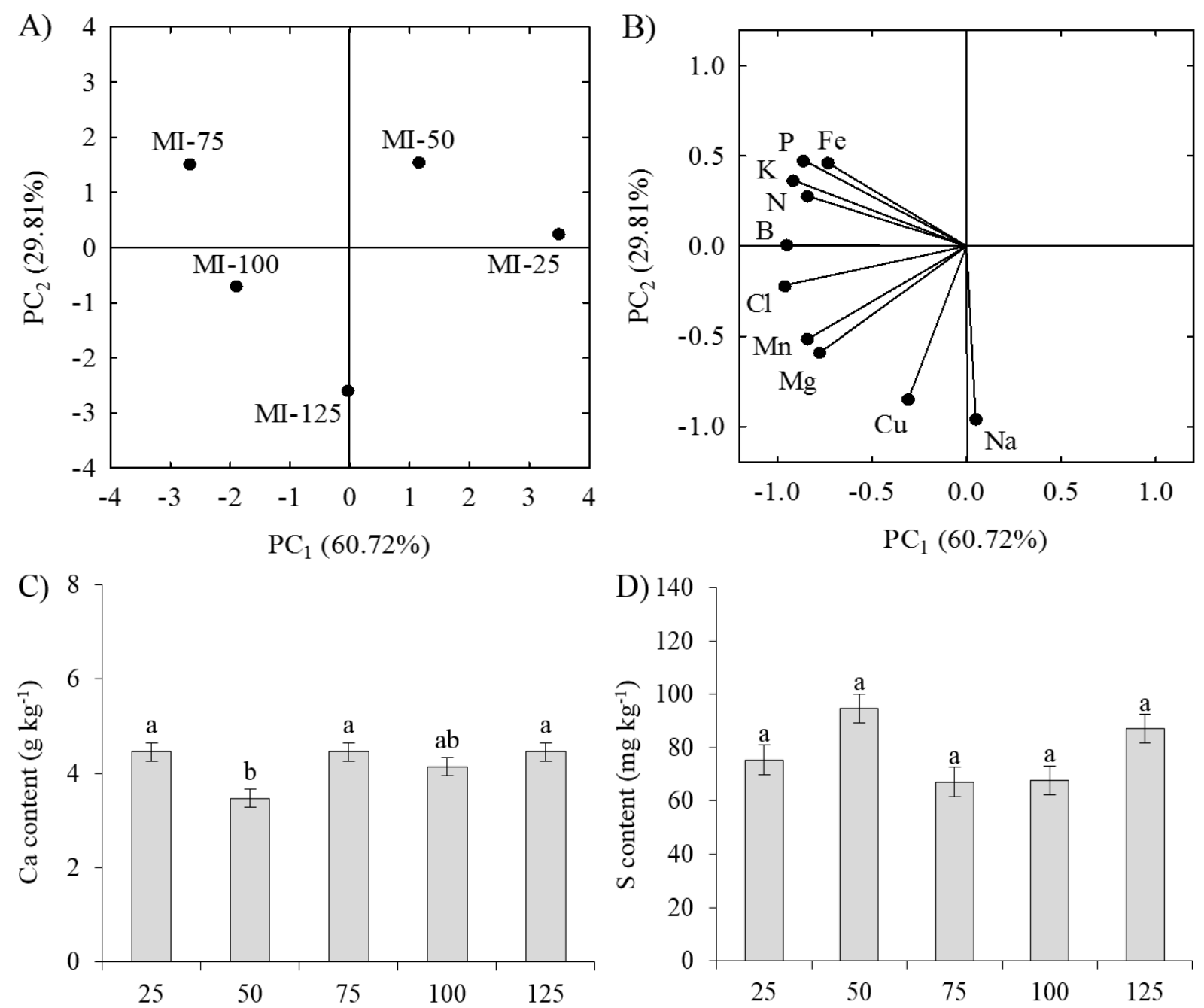

ETo replacement levels (\%)
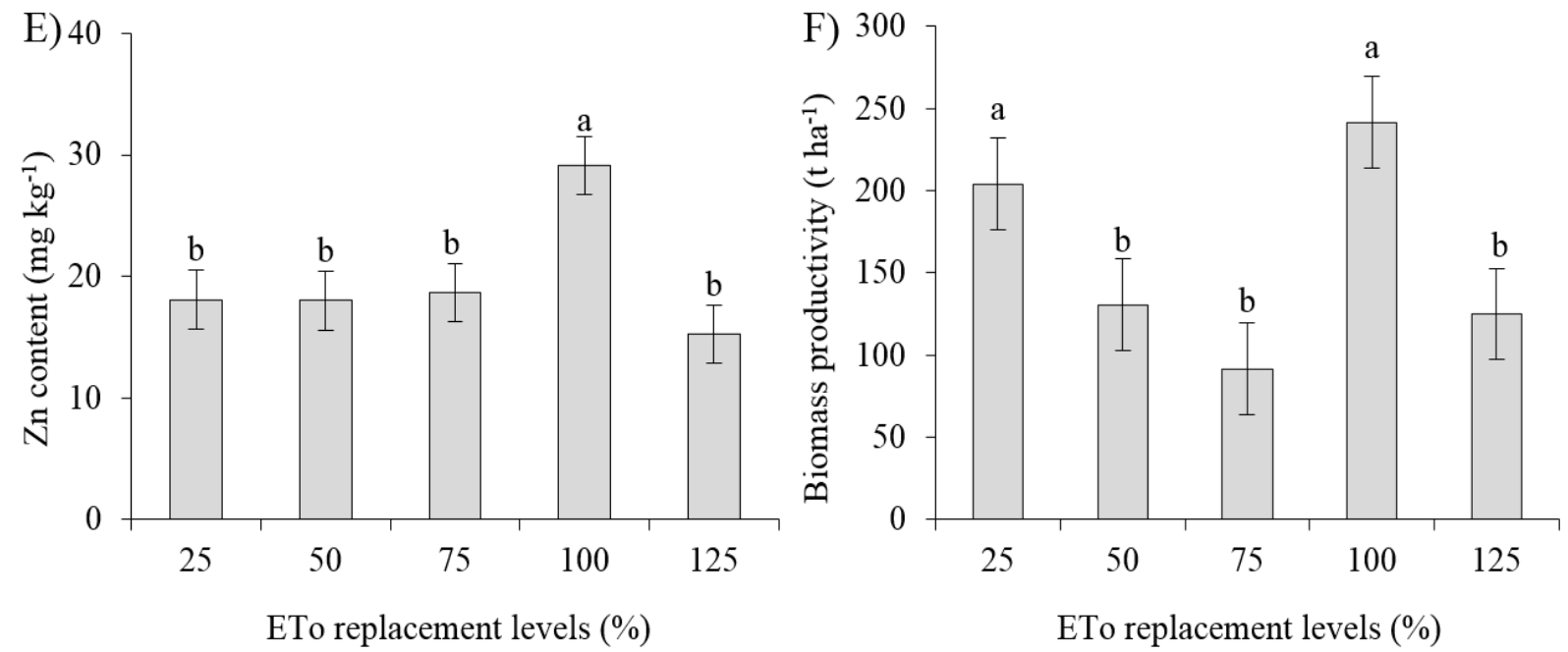

ETo replacement levels (\%)

ETo replacement levels (\%)

Figure 2. Two-dimensional projection (Biplot) of ETo replacement levels (A) and correlation of variables (B) in the first two Principal Components $\left(\mathrm{PC}_{1}\right.$ and $\left.\mathrm{PC}_{2}\right), \mathrm{Ca}(\mathrm{C}), \mathrm{S}(\mathrm{D})$ and $\mathrm{Zn}(\mathrm{E})$ contents and $\mathrm{BP}(\mathrm{F})$ for the forage cactus variety 'Miúda' under water replacement levels.

For the forage cactus 'Miúda' (Nopalea cochenillifera (L.) Salm-Dyck), the classic contents of macronutrients, in $\mathrm{g} \mathrm{kg}^{-1}$ of dry matter, reported in the literature are: $\mathrm{N}$ (6.7-10.5), $\mathrm{P}$ (1.0-1.6), K (8.3-12.1), Ca (20.6-22.5), Mg (10.4-17.0) and S (0.9-1.9). The classic contents of micronutrientes, in $\mathrm{mg} \mathrm{kg}^{-1}$ of dry matter, are: $\mathrm{Cu}(4.0), \mathrm{Fe}$ (59.0), $\mathrm{Mn}(430.0), \mathrm{Zn}(70.0)$ and 
$\mathrm{Na}$ (143.0) (Germano et al., 1991; Batista et al., 2003; Menezes et al., 2005; Santos et al., 2006; Frota et al., 2015).

The forage cactus 'Miúda' had higher accumulation of $\mathrm{N}, \mathrm{K}, \mathrm{Ca}, \mathrm{Mg}, \mathrm{Cu}, \mathrm{Fe}, \mathrm{Mn}$ and $\mathrm{Na}$ than those reported in the literature for the species Nopalea cochenillifera (L.) Salm-Dyck, while the contents of $\mathrm{P}, \mathrm{S}$ and $\mathrm{Zn}$ were lower. The observed increments occurred because the replacement levels of 75, 100 and $125 \%$ ETo promoted higher water availability in the soil and favored greater water absorption, rise and transpiration by plants, and this process is fundamental for the assimilation and remobilization of nutrients (Taiz et al., 2017).

Greater availability of water and nitrogen may have induced the growth and development of roots, because the forage cactus has a root system formed by many thin roots $(<1 \mathrm{~mm})$ distributed in a network, located in the surface layer of the soil profile $(0-20 \mathrm{~cm})$, adapted for absorbing water from light rains and even dew. Thus, greater water supply may have promoted root growth in deeper layers due to percolation of water and transport of nutrients to these zones (Oliveira et al., 2010). It must be pointed out that in areas of arid and semiarid climate, soil moisture is usually the main factor influencing root growth (Wilcox et al., 2004).

The above-mentioned information is ratified by Snyman (2006), who found that the mass and length of forage cactus roots decreased significantly under water deficit, while the root mass/length ratio increased significantly. In this context, the supply of water and nitrogen may have promoted greater accumulation of root biomass, besides stimulating root elongation, increasing the specific surface for nutrient absorption, which justifies the high contents quantified in this study.

The low content of $\mathrm{P}$ observed under $25 \%$ ETo replacement may be related to its low mobility in the soil (Santos et al., 2008). In addition, the low soil moisture content inhibits mycorrhizal colonization and reduces nutrient absorption, notably due to the smaller diameter of the fungi hyphae and consequent reduction in the hypha-soil contact surface, converged to limit the ability to store polyphosphates in vacuoles (Santos, 2018).

Indeed, the low moisture may have limited these processes, especially since these fungi increase the availability of nutrients, notably those with lower mobility, as in the case of phosphorus (Abboud et al., 2018), enhance water absorption and ensure greater drought resistance in host plants (Balota et al., 2011). Complementarily, the reduction of $\mathrm{P}$ content under $125 \%$ ETo replacement may have occurred due to the greater solubilization and flow of the mass of water with phosphate to deeper layers, where there is lower root density, and to the transport of the nutrient (Costa et al., 2014).

For the forage cactus 'Orelha de Elefante Mexicana', two Principal Components $\left(\mathrm{PC}_{1}\right.$ and $\mathrm{PC}_{2}$ ) were formed with eigenvalues greater than one, with accumulated total variance of $87.01 \%$ in the experiment. The contents of $\mathrm{N}, \mathrm{P}, \mathrm{Ca}, \mathrm{Na}, \mathrm{Cl}, \mathrm{S}, \mathrm{B}$, and Fe were combined to form $\mathrm{PC}_{1}$, which accounts for $47.73 \%$ of the total variance, while $\mathrm{PC}_{2}$ accounts for $39.28 \%$ of the remaining variance and was formed by the linear combination of the $\mathrm{Mg}, \mathrm{Cu}, \mathrm{Zn}$ and $\mathrm{Mn}$ contents (Table 4). K contents and $\mathrm{BP}$ were not related in $\mathrm{PC}_{1}$ and $\mathrm{PC}_{2}$.

The absolute contents of macro and micronutrients in the forage cactus 'Orelha de Elefante Mexicana' obtained at each level of ETo replacement are presented in Table 4. Regardless of ETo replacement level, the order of magnitude of macronutrient accumulation in the cladodes of 'Orelha de Elefante Mexicana', in $\mathrm{g} \mathrm{kg}^{-1}$, was: $\mathrm{Ca}(45.24 \pm 5.60)>\mathrm{Mg}(21.77 \pm 1.41)>\mathrm{N}$ $(18.17 \pm 2.48)>\mathrm{K}(18.15 \pm 2.48)>\mathrm{P}(1.90 \pm 0.31)>\mathrm{S}(0.07 \pm 0.03)$; and for micronutrients, in $\mathrm{mg}$ $\mathrm{kg}^{-1}$, the order was: $\mathrm{Cl}(65508.00 \pm 7943.64)>\mathrm{Na}(2906.00 \pm 1309.76)>\mathrm{Mn}(995.66 \pm 163.35)>$ $\mathrm{Fe}(108.08 \pm 34.41)>\mathrm{B}(105.41 \pm 19.56)>\mathrm{Zn}(22.65 \pm 3.17)>\mathrm{Cu}(13.44 \pm 2.56)$. 
Table 4. Eigenvalues, variance, coefficients of correlation between Principal Components and variables and means of treatments for the forage cactus variety 'Orelha de Elefante Mexicana'.

\begin{tabular}{|c|c|c|c|c|c|c|c|c|c|c|c|c|c|c|c|c|c|}
\hline \multirow{2}{*}{ PCs } & \multirow{2}{*}{$\lambda$} & \multirow{2}{*}{$\sigma^{2} \%$} & \multirow{2}{*}{$P$} & \multicolumn{14}{|c|}{ Factorial Loadings (r) } \\
\hline & & & & $\mathbf{N}^{1}$ & $\mathrm{P}^{1}$ & $\mathrm{~K}^{1}$ & $\mathrm{Ca}^{1}$ & $\mathrm{Mg}^{1}$ & $\mathrm{Na}^{1}$ & $\mathrm{Cl}^{1}$ & $\mathrm{~S}^{2}$ & $\mathrm{~B}^{2}$ & $\mathrm{Cu}^{2}$ & $\mathrm{Zn}^{2}$ & $\mathrm{Fe}^{2}$ & $\mathrm{Mn}^{2}$ & $\mathrm{BP}^{3}$ \\
\hline \multirow[t]{7}{*}{$\mathrm{PC}_{2}$} & 4.71 & 39.28 & $<0.001$ & 0.40 & 0.43 & $\mathrm{R}$ & -0.57 & $0.97^{*}$ & 0.63 & 0.04 & 0.52 & 0.01 & $0.68^{*}$ & $0.98^{*}$ & -0.20 & $-0.98^{*}$ & $\mathrm{R}$ \\
\hline & ETo & & & & & & & & & & Means & & & & & & \\
\hline & $25 \%$ & & & 23.80 & 0.22 & 16.82 & 44.50 & 23.98 & 3.22 & 57.24 & 93.44 & 95.32 & 15.96 & 26.79 & 126.10 & 803.63 & 280.55 \\
\hline & $50 \%$ & & & 18.03 & 0.17 & 16.12 & 49.50 & 21.74 & 2.13 & 61.48 & 63.76 & 102.69 & 12.74 & 22.33 & 104.73 & 1058.23 & 213.89 \\
\hline & $75 \%$ & & & 17.68 & 0.16 & 18.94 & 49.50 & 19.55 & 1.73 & 63.60 & 35.38 & 112.33 & 11.94 & 17.10 & 167.16 & 1262.35 & 686.10 \\
\hline & $100 \%$ & & & 17.50 & 0.18 & 22.66 & 48.00 & 21.53 & 2.12 & 64.66 & 98.60 & 78.88 & 9.86 & 22.99 & 81.13 & 1004.77 & 538.88 \\
\hline & $125 \%$ & & & 13.83 & 0.13 & 16.19 & 34.65 & 22.05 & 5.33 & 80.56 & 40.54 & 137.84 & 16.72 & 24.06 & 156.28 & 849.32 & 416.66 \\
\hline
\end{tabular}

PCs: principal components; $\lambda$ : eigenvalues; $\sigma^{2} \%$ : portion of the variance explained; $1:$ means in $\mathrm{g} \mathrm{kg}^{-1} ; 2: \mathrm{means} \mathrm{in} \mathrm{mg} \mathrm{kg}^{-1} ; 3:$ means in $\mathrm{t}$ $\mathrm{ha}^{-1}$; ETo: reference evapotranspiration; R: variable removed from principal component analysis; P: probability of the significance test by

Hotelling's test; and *: variables considered in the PC; $r=0.10-0.30$ (weak correlation); $r=0.40-0.60$ (moderate correlation); $r=0.70-1.00$ (strong correlation).

It was found that, in $\mathrm{PC}_{1}$, the forage cactus $\mathrm{OR}$ had higher relative accumulation of $\mathrm{N}, \mathrm{P}$ and $\mathrm{S}$ under $25 \%$ ETo replacement. Also in $\mathrm{PC}_{1}$, the OR variety obtained a higher $\mathrm{Ca}$ content with $50 \%$ ETo replacement, more substantial contents of $\mathrm{Na}, \mathrm{Cl}$ and $\mathrm{B}$ under $125 \% \mathrm{ETo}$, and higher accumulation of $\mathrm{Fe}$ when $75 \%$ ETo replacement. $\mathrm{In}_{2}$, the forage cactus variety $\mathrm{OR}$ had a higher relative accumulation of $\mathrm{Mg}$ and $\mathrm{Zn}$ with the replacement of $25 \%$ ETo, while higher relative contents of $\mathrm{Mn}$ and $\mathrm{Cu}$ were obtained in plants subjected to $75 \%$ and $125 \%$ ETo, respectively (Figure $3 \mathrm{~A}$ and B). K contents did not differ in response to the ETo replacement levels (Figure $3 \mathrm{C}$ ). Higher biomass productivity (BP) was obtained when 'Orelha de Elefante Meicana' was irrigated with 75\% ETo, showing intermediate productivity under replacements of 100 and $125 \%$ ETo and lower productivity under replacements of 25 and $50 \%$ ETo (Figure 3 D). 

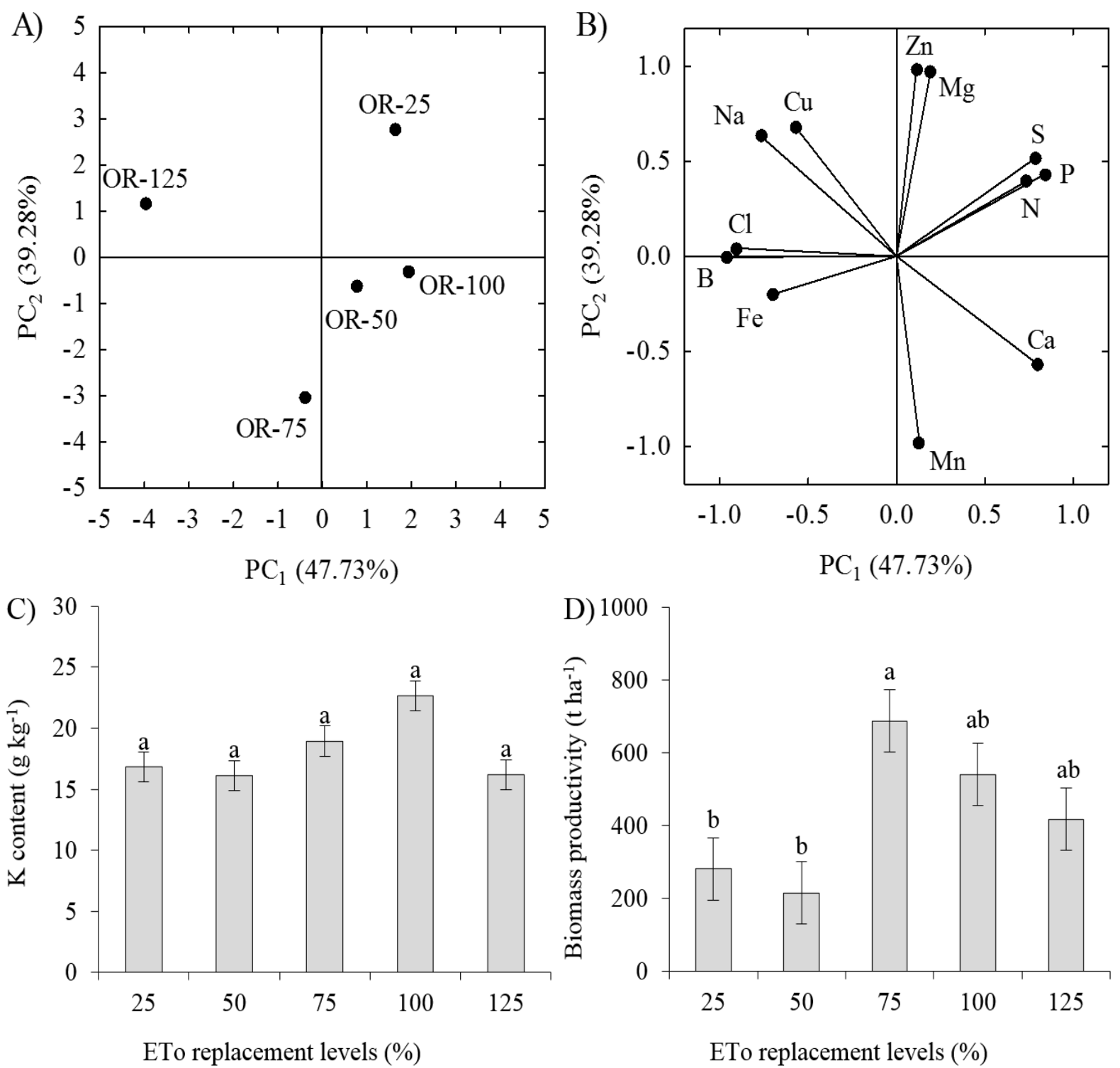

Figure 3. Two-dimensional projection (Biplot) of ETo replacement levels (A) and correlation of variables $(\mathrm{B})$ in the first two Principal Components $\left(\mathrm{PC}_{1}\right.$ and $\left.\mathrm{PC}_{2}\right), \mathrm{K}$ content $(\mathrm{C})$ and $\mathrm{BP}(\mathrm{D})$ for the forage cactus variety 'Orelha de Elefante Mexicana' under water replacement levels.

In the pertinent literature, the classic contents of macronutrients in forage cactus (Opuntia ficus-indica (L.) Mill), a species of the variety 'Orelha de Elefante Mexicana', in $\mathrm{g} \mathrm{kg}^{-1}$ of dry matter, are: N (6.7-20.6), P (0.8-4.7), K (23.0-33.4), Ca (14.9-42.0), Mg (5.9-14.0) and S (1.7$6.1)$; and the classic contents of micronutrients, in $\mathrm{mg} \mathrm{kg}^{-1}$ of dry matter, are: $\mathrm{Fe}$ (77.0-128.0), $\mathrm{Zn}$ (62.0-108.6), Mn (182.0-686.9), $\mathrm{Cu}$ (4.0-1 2.2), B (15.8-22.4) and $\mathrm{Na}$ (40.2-135.9) (Menezes et al., 2005; Silva et al., 2012).

The contents of $\mathrm{Ca}, \mathrm{Mg}, \mathrm{Na}, \mathrm{B}, \mathrm{Cu}$ and $\mathrm{Mn}$ in the variety 'Orelha de Elefante Mexicana' were higher than those reported in the literature, except for Ca contents under replacement of $125 \%$ ETo and $\mathrm{Cu}$ contents under replacements of 75 and $100 \%$ ETo, which are within the concentration range reported for the species. $\mathrm{N}$ and Fe contents are within the concentrations reported in the literature, except under replacement of $25 \%$ ETo, where the accumulation of $\mathrm{N}$ is higher, and under replacements of 75 and $100 \%$ ETo, where Fe contents are higher. The contents of $\mathrm{P}, \mathrm{K}, \mathrm{S}$ and $\mathrm{Zn}$ are below the concentration range.

The high contents of $\mathrm{Ca}, \mathrm{Mg}, \mathrm{Na}, \mathrm{B}, \mathrm{Cu}$ and $\mathrm{Mn}$ may be related to the greater availability of water and nitrogen in the soil due to fertigation, a situation that promotes the development 
of adaptation mechanisms for better absorption of water and nutrients in arid and semiarid regions (Edvan et al., 2013). There may have been a change in root structure, especially increase in the absorption surface, notably due to the inhibition of growth of the main root and stimulation of growth and density of lateral roots and root hairs, besides the increase in their diameter and hydraulic conductivity (Morgan and Connolly, 2013; Xia et al., 2018).

In addition to root changes, the greater supply of water and nitrogen may have increased water potential and turgor pressure in the cells, resulting in a higher concentration of organic solutes in the cytosol and extracellular matrices, a condition that leads to osmotic adjustment and may have influenced the transpiration flow and the consequent influx of water and nutrients into plants (Merwad et al., 2018). Indeed, the accumulation of $\mathrm{K}, \mathrm{Cl}, \mathrm{Na}$ and nitrate $\left(\mathrm{NO}_{3}-\right)$ may have stimulated cell elongation and division in the apical meristem region of lateral roots, contributing to greater growth and exploration of the soil profile and consequent interception and absorption of nutrients by the roots of the variety 'Orelha de Elefante Mexicana' (Taiz et al., 2017).

The reduction in phosphorus contents observed with the increment in ETo replacement levels are probably related to the leaching caused by the greater dissociation of phosphate granules and water percolation movement by mass flow, conditions that enabled phosphate movement between soil particles to deeper regions (Harger et al., 2007; Gonçalves et al., 2008; Costa et al., 2014).

In another perspective, there may have been adsorption and precipitation of $\mathrm{P}$ to soil particles and to organic matter, notably due to electrostatic or covalent bonds and the consequent formation of insoluble compounds, which makes the element unavailable for plants (Corrêa et al., 2011). Indeed, the increase in water supply in the soil may have promoted greater biomass accumulation in spontaneous plants (weed) and consequent increase in organic matter, which favors greater adsorption and complexation of $\mathrm{P}$ to $\mathrm{Fe}$ oxides, $\mathrm{Al}$ oxides and clay minerals, due to the occupation of adsorption sites (Abboud et al., 2018).

According to Silva (2017), the increase in ETo replacement levels associated with the greater availability of $\mathrm{N}$ via fertigation promoted greater accumulation of biomass in the cladodes of the forage cactus variety 'Orelha de Elefante Mexicana'. These increments in water and biomass may have favored greater remobilization of $\mathrm{P}$ in the cladode tissues, due to the high mobility of $\mathrm{P}$ in the plant (Luengo et al., 2018), which reflects greater nutrient dilution effect on parenchymatic tissues of the forage cactus (Dubeux Júnior et al., 2006).

The low K contents recorded in the variety 'Orelha de Elefante Mexicana' are possibly due to the leaching of the nutrient to deeper zones that are not explored by the root system. This information is ratified by Albuquerque et al. (2011), who mentioned that unabsorbed $\mathrm{K}$ is leached, and this process is responsible for up to $10 \%$ of $\mathrm{K}$ losses in the rhizosphere. It should be emphasized that the mobility of $\mathrm{K}^{+}$ions in the soil occurs primarily by diffusion, so the amount of $\mathrm{K}$ reaching the roots by mass flow is much lower than the absorption rate, justifying the low contents recorded even in irrigated cultivation (Neves et al., 2009).

Conversely, it is possible that excess salts in irrigation water $\left(\mathrm{C}_{3} \mathrm{~S}_{1}\right)$, besides limiting water availability, may have caused nutritional disorders in the plant, notably for preventing the absorption of $\mathrm{K}$, which converges to nutritional unbalance (Albuquerque et al., 2011). In this context, it can be inferred that there was an absorption of $\mathrm{Na}$ instead of $\mathrm{K}$, given the high $\mathrm{Na}$ content found in the cladode tissues. Indeed, Na may have acted on the enzymatic activation of ATPase, osmoregulation, absorption of macronutrients, cell permeability, carbohydrate synthesis, stomatal opening and closure, and in the transport of carbon dioxide (Inocencio et al., 2014).

The low contents of $\mathrm{S}$ in the cladodes may have occurred because excess water carried the nutrient to deeper layers, especially because of its high mobility in the soil. This is due to the high contents of $\mathrm{Na}$ from the irrigation water, which may have been linked to sulfate $\left(\mathrm{SO}_{4}{ }^{2-}\right)$, 
which can be confirmed by the increase in the solubilization of ions, such as $\mathrm{Ca}^{2+}$ and $\mathrm{Mg}^{2+}$, notably by the high contents of these nutrients found in the cladodes (Giordano and Raven, 2014; Araujo et al., 2015). The low contents of $\mathrm{Zn}$ in the cladodes may have occurred due to the greater supply of organic matter resulting from the increase of weed and consequent adsorption of this nutrient to the organic fraction or to $\mathrm{Fe}$ and $\mathrm{Al}$ oxides in the soil matrix (Smanhotto et al., 2010).

\section{CONCLUSIONS}

The mineral composition of the forage cactus varieties 'Miúda' and 'Orelha de Elefante Mexicana' can be optimized from soil water management, so as to obtain adequate nutritional balance for higher yield.

The replacement level of $75 \%$ ETo promoted greater balance between nutrients in the cladodes of the forage cactus variety 'Miúda', while 'Orelha de Elefante Mexicana' had better nutritional balance with the replacement levels of 100 and $125 \%$ ETo.

Soil water replacement levels of 100 and $125 \%$ ETo promote high accumulation of $\mathrm{Na}^{+}$ and $\mathrm{Cl}^{-}$ions in the cladodes of the forage cactus varieties studied.

Highest biomass productivity of the varieties 'Orelha de Elefante Mexicana' and 'Miúda' was obtained with 75 and 100\% ETo replacement levels, respectively.

Among the varieties, 'Orelha de Elefante Mexicana' had higher capacity to accumulate nutrients and biomass productivity, followed by 'Miúda' under the edaphoclimatic conditions of the Brazilian semiarid region.

\section{REFERENCES}

ABBOUD, F. Y.; FAVARETTO, N.; MOTTA, A. C. V.; BARTH, G.; GOULARTE, G. D. Phosphorus mobility and degree of saturation in oxisol under no-tillage after long-term dairy liquid manure application. Soil \& Tillage Research, v. 177, p. 45-53, 2018. https://doi.org/10.1016/j.still.2017.11.014

ALbUQUERQUE, F. da S.; SILVA, E. F. de F. e; SOUZA, A. E. R. de; ROLIM, M. M. Lixiviação de potássio em um cultivo de pimentão sob lâminas de irrigação e doses de potássio. Revista Caatinga, v. 24, n. 3, p. 135-144, 2011.

ARAUJO, J. L.; SEVERO, P. J. da S.; LUCENA, F. T. C.; VERIATO, R. G.; PAIVA, K. F. de. Enxofre elementar ou sulfato de cálcio para remediação de solos salino-sódicos? Pesquisa Agropecuária Tropical, v. 45, n. 4, p. 388-396, 2015. https://doi.org/10.1590/1983-40632015v4537090

BALOTA, E. L.; MACHINESKI, O.; STENZEL, N. M. C. Resposta da acerola à inoculação de fungos micorrízicos arbusculares em solo com diferentes níveis de fósforo. Bragantia, v. 70, n. 1, p. 166-175, 2011. https://doi.org/10.1590/S0006-87052011000100023

BATISTA, A. M. V.; MUSTAFA, A. F.; MCALliSTER, T.; WANG, Y.; SOITA, H.; MCKINNON, J. J. Effects of variety on chemical composition, in situ nutrient disappearance and in vitro gas production of spineless cacti. Journal of the Science of Food and Agriculture, v. 83, n. 5, p. 440-445, 2003. https://doi.org/10.1002/jsfa.1393

BENITES-LAZARO, L. L.; GIATTI, L. L.; SOUSA JUNIOR, W. C.; GIAROLLA, A. Landwater-food nexus of biofuels: Discourse and policy debates in Brazil. Environmental Development, v. 33, p. 100491, 2020. https://doi.org/10.1016/j.envdev.2019.100491 
CARDOSO, D. B.; CARVALHO, F. F. R.; MEDEIROS, G. R.; GUIM, A.; CABRAL, A. M. D.; VÉRAS, R. M. L.; SANTOS, K. C.; DANTAS, L. C. N.; NASCIMENTO, A. G. O. Levels of inclusion of spineless cactus (Nopalea cochenillifera Salm Dyck) in the diet of lambs. Animal Feed Science and Technology, v. 247, p. 23-31, 2019. https://doi.org/10.1016/j.anifeedsci.2018.10.016

CORRÊA, R. M.; NASCIMENTO, C. W. A.; ROCHA, A. T. Adsorção de fósforo em dez solos do Estado de Pernambuco e suas relações com parâmetros físicos e químicos. Acta Scientiarum. Agronomy, v. 33, n. 1, p. 153-159, 2011. https://doi.org/10.4025/actasciagron.v33i1.3129

COSTA, L. A. de M.; COSTA, M. S. S. de M.; PEREIRA, D. C. Lixiviação do fósforo do solo por meio de adubos fosfatados e palhas de plantas de cobertura. Revista Varia Scientia Agrárias, v. 4, n. 1, p. 23-37, 2014. https://doi.org/10.13140/RG.2.2.19333.96480

DANCEY, C.; REIDY, J. Estatística sem matemática para psicologia. Porto Alegre: Artmed, 2013. 608 p.

DUBEUX JÚNIOR, J. C. B.; SANTOS, M. V. F. dos; LIRA, M. de A.; SANTOS, D. C. dos; FARIAS, I.; LIMA, L. E.; FERREIRA, R. L. C. Productivity of Opuntia fícus-indica (L.) Mill., under different $\mathrm{N}$ and $\mathrm{P}$ fertilization and plant population in North- east Brazil. Journal of Arid Environments, v. 67, n. 3, p. 357-372, 2006. https://doi.org/10.1016/j.jaridenv.2006.02.015

EDVAN, R. L.; FERNANDES, P. D.; CARNEIRO, M. S. de S.; NEDER, D. G.; ARAUJO, J. S.; ANDRADE, A. P. de; SOUTO FILHO, L. T. Acúmulo de biomassa e crescimento radicular da palma forrageira em diferentes épocas de colheita. Revista Acadêmica: Ciências Agrárias e Ambientais, v. 11, n. 4, p. 373-381, 2013. http://dx.doi.org/10.7213/academico.011.004.AO04

EMBRAPA. Manual de análises químicas de solos, plantas e fertilizantes. 2. ed. rev. ampl. Brasília: Embrapa informação Tecnológica, 2009. 627 p.

FERRAZ, R. L. S; COSTA, P. S.; DANTAS NETO, J.; VIÉGAS, P. R. A.; MELO, A. S.; COSTA, F. S.; MEDEIROS, A. S.; MAGALHÃES, I. D.; LIMA, A. S.; CAVALCANTE JÚNIOR, C. A.; LIMA, V. L. A. Estimation of productivity gain by irrigated and fertilized forage palm plants (Opuntia ficus-indica (L.) Mill. and Nopalea cochenillifera (L.) SalmDyck): systematic review and meta-analysis. Australian Journal of Crop Science, v. 13, n. 11, p. 1873-1882, 2019.

FROTA, M. N. L.; CARNEIRO, M. S. de S.; CARVALHO, G. M. C.; ARAÚJO NETO, R. B. de. Palma Forrageira na Alimentação Animal. 21. ed. Teresina: Embrapa Meio-Norte, 2015. $47 \mathrm{p}$.

GERMANO, R. H.; BARBOSA, H. P.; COSTA, R. G.; MEDEIROS, A. N. Avaliação da composição química e mineral de seis cactáceas do semi-árido paraibano. In: REUNIÃO DA SOCIEDADE BRASILEIRA DE ZOOTECNIA, 28., 1991, João Pessoa. Anais[...] João Pessoa: Sociedade Brasileira de Zootecnia, 1991. p. 3.

GIORDANO, M.; RAVEN, J. A. Nitrogen and sulfur assimilation in plants and algae. Aquatic Botany, v. 118, p. 45-61, 2014. https://doi.org/10.1016/j.aquabot.2014.06.012

GONÇALVES, G. K.; SOUSA, R. O.; VAHL, L. C.; BORTOLON, L. Solubilização dos fosfatos naturais patos de minas e arad em dois solos alagados. Revista Brasileira de Ciência do Solo, v. 32, n. 5, p. 2157-2164, 2008. https://doi.org/10.1590/S010006832008000500036 
GOVAERTS, B.; SAYRE, K. D.; LICHTER, K.; DENDOOVEN, L.; DECKERS, J. Influence of permanent raised bed planting and residue management on physical and chemical soil quality in rain fed maize/wheat systems. Plant and Soil, v. 291, p. 39-54, 2007. https://doi.org/10.1007/s11104-006-9172-6

HAIR Jr., F. J.; BLACK, W. C.; BABIN, B. J.; ANDERSON, R. E.; TATHAM, R. L. Análise Multivariada de Dados. 6. ed. Porto Alegre: Bookman, 2009.

HARGER, N.; BRITO, O. R.; RALISCH, R.; ORTIZ, F. R.; WATANABE, T. S. Avaliação de fontes e doses de fósforo no crescimento inicial do milho. Semina: Ciências Agrárias, v. 28, n. 1, p. 39-44, 2007. https://doi.org/10.5433/1679-0359.2007v28n1p39

INOCENCIO, M. F.; CARVALHO, J. G. de; FURTINI NETO, A. E. Potássio, sódio e crescimento inicial de espécies florestais sob substituição de potássio por sódio. Revista Árvore, v. 38, n. 1, p. 113-123, 2014. https://doi.org/10.1590/S010067622014000100011

KÖPPEN, W.; GEIGER, R. Klimate der Erde. Gotha: Verlag Justus Perthes, 1928. Wall-map.

KRÜMPEL, J.; GEORGE, T.; GASSTON, B.; FRANCIS, G.; LEMMER, A. Suitability of Opuntia ficus-indica Opuntia ficus-indica (L) Mill. and Euphorbia tirucalli L. as energy crops for anaerobic digestion. Journal of Arid Environments, v. 174, p. 104047, 2020. https://doi.org/10.1016/j.jaridenv.2019.104047

LIGUORI, G.; GENTILE, C.; GAGLIO, R.; PERRONE, A.; GUARCELLO, R.; FRANCESCA, N.; FRETTO, S.; INGLESE, P.; SETTANNI, L. Effect of addition of Opuntia ficus-indica mucilage on the biological leavening, physical, nutritional, antioxidant and sensory aspects of bread. Journal of Bioscience and Bioengineering, $\mathrm{v}$. 129, n. 2, p. 184-191, 2020. https://doi.org/10.1016/j.jbiosc.2019.08.009

LUENGO, R. de F. A.; BUTRUILLE, N. M. dos S.; MELO, R. A. de C. e; SILVA, J. da; MALDONADE, I. R.; COSTA JÚNIOR, A. D. Determinação de minerais no solo e análise de folhas de couve produzida em Brasília. Brazilian Journal of Food Technology, v. 21, p. 1-9, 2018. https://doi.org/10.1590/1981-6723.14117

MEDEIROS, A. S.; MAIA, S. M. F.; SANTOS, T. C.; GOMES, T. C. A. Soil carbon losses in conventional farming systems due to land-use change in the Brazilian semi-arid region. Agriculture, Ecosystems \& Environment, v. 287, p. 106690, 2020. https://doi.org/10.1016/j.agee.2019.106690

MENEZES, R. S. C.; SIMÕES, D. A.; SAMPAIO, E. V. S. B. A palma no Nordeste do Brasil: conhecimento atual e novas perspectivas de uso. 2. ed. Recife: Editora Universitária da UFPE, 2005. $258 \mathrm{p}$.

MERWAD, A. R. M. A.; DESOKY, E. S. M.; RADY, M. M. Response of water deficit-stressed Vigna unguiculata performances to silicon, proline or methionine foliar application. $\begin{array}{llllll}\text { Scientia Horticulturae, } & \text { v. 228, } & \text { p. }\end{array}$ https://doi.org/10.1016/j.scienta.2017.10.008

MORGAN, J. B.; CONNOLLY, E. L. Plant-Soil Interactions: Nutrient Uptake. Nature Education Knowledge, v. 4, n. 8, 2013.

MOURA, M. S. C.; GUIM, A.; BATISTA, A. M. V.; MACIEL, M. V.; CARDOSO, D. B.; LIMA JÚNIOR, D. M.; CARVALHO, F. F. R. The inclusion of spineless cactus in the diet of lambs increases fattening of the carcass. Meat Science, v. 160, p. 107975, 2020. https://doi.org/10.1016/j.meatsci.2019.107975 
NEVES, L. S. das; ERNANI, P. R.; SIMONETE, M. A. Mobilidade de potássio em solos decorrente da adição de doses de cloreto de potássio. Revista Brasileira de Ciência do Solo, v. 33, p. 25-32, 2009. https://doi.org/10.1590/S0100-06832009000100003

OLIVEIRA, F. T. de; SOUTO, J. S.; SILVA, R. P. da; ANDRADE FILHO, F. C. de; PEREIRA JÚNIOR, E. B. Palma forrageira: adaptação e importância para os ecossistemas áridos e semiáridos. Revista Verde de Agroecologia e Desenvolvimento Sustentável, v. 5, n. 4, p. 27-37, 2010.

QUEIROZ, M. G.; SILVA, T. G. F.; ZOLNIER, S.; JARDIM, A. M. R. F.; SOUZA, C. A. A.; RAÚJO JÚNIOR, G. N.; MORAIS, J. E. F.; SOUZA, L. S. B. Spatial and temporal dynamics of soil moisture for surfaces with a change in land use in the semi-arid region of Brazil. Catena, v. 188, p. 104457, 2020. https://doi.org/10.1016/j.catena.2020.104457

REZENDE, F. M.; VÉRAS, A. S. C.; SIQUEIRA, M. C. B.; CONCEIÇÃO, M. G.; LIMA, C. L.; ALMEIDA, M. P.; MORA-LUNA, R. E.; NEVES, M. L. M. W.; MONTEIRO, C. C. F.; FERREIRA, M. A. Nutritional effects of using cactus cladodes (Opuntia stricta Opuntia stricta Haw Haw) to replace sorghum silage in sheep diet. Tropical Animal Health and Production, v. 52, p. 1875-1880, Edinburgh, 2020. https://doi.org/10.1007/s11250-02002213-w

SALEHI, E.; EMAM-DJOMEH, Z.; ASKARI, G.; FATHI, M. Opuntia ficus indica fruit gum: Extraction, characterization, antioxidant activity and functional properties. $\begin{array}{llllll}\text { Carbohydrate Polymers, } & \text { v. 206, p. } & \text { 565-572, }\end{array}$ https://doi.org/10.1016/j.carbpol.2018.11.035

SANTANA, R. A.; BEZERRA, S. T. M.; SANTOS, S. M.; COUTINHO, A. P.; COELHO, I. C. L.; PESSOA, R. V. S. Assessing alternatives for meeting water demand: A case study of water resource management in the Brazilian Semiarid region. Utilities Policy, v. 61, p. 100974, 2019. https://doi.org/10.1016/j.jup.2019.100974

SANTOS, C. A. C.; MARIANO, D. A.; NASCIMENTO, F. C. A.; DANTAS, F. R. C.; OLIVEIRA, G.; SILVA, M. T.; SILVA, L. L.; SILVA, B. B.; BEZERRA, B. G.; SAFA, B.; MEDEIROS, S. S.; NEALE, C. M. U. Spatio-temporal patterns of energy exchange and evapotranspiration during an intense drought for drylands in Brazil. International Journal of Applied Earth Observation and Geoinformation, v. 85, p. 101982, 2020. https://doi.org/10.1016/j.jag.2019.101982

SANTOS, D. C. dos; FARIAS, I.; LIRA, M. de A.; SANTOS, M. V. F. dos; ARRUDA, G. P. de; COELHO, R. S. B.; DIAS, F. M.; MELO, J. N. de. Manejo e utilização da palma forrageira (Opuntia e Nopalea) em Pernambuco. Recife: IPA, 2006. 48 p. (IPA. Documentos, 30).

SANTOS, D. R. dos; GATIBONI, L. C.; KAMINSKI, J. Fatores que afetam a disponibilidade do fósforo e o manejo da adubação fosfatada em solos sob sistema plantio direto. Ciência Rural, v. 38, n. 2, p. 576-586, 2008. https://doi.org/10.1590/S0103-84782008000200049

SANTOS, R. P. R. Avaliação da taxa de colonização por fungos micorrízicos arbusculares em solo em consórcio com resíduos de corte de granito e macrófitas aquáticas. Revista Gestão e Sustentabilidade Ambiental, v. 7, n. 2, p. 690-703, 2018. https://doi.org/10.19177/rgsa.v7e22018690-703 
SILVA, A. S.; SANTOS, E. M.; RAMOS, J. P. F.; PERAZZO, A. F.; MUNIZ, A. C. S.; SANTOS, F. N. S.; PEREIRA, D. M.; CRUZ, G. F. L. Características agronômicas de variedades de Opuntia cochenillifera e Nopalea cochenillifera sob diferentes densidades de plantio. Colloquium Agrariae, v. 15, n. 6, p. 88-96, 2019. https://doi.org/10.5747/ca.2019.v15.n6.a340

SILVA, J. A. da; BONOMO, P.; DONATO, S. L. R.; PIRES, A. J. V.; ROSA, R. C. C.; DONATO, P. E. R. Composição mineral em cladódios de palma forrageira sob diferentes espaçamentos e adubações química. Revista Brasileira de Ciências Agrárias, v. 7, p. 866-875, 2012. https://doi.org/10.5039/agraria.v7isa2134

SILVA, P. F. da. Crescimento e produtividade de palma forrageira sob diferentes lâminas de irrigação e adubação nitrogenada. 2017. 79f. Tese (Doutorado em Engenharia Agrícola) - Universidade Federal de Campina Grande, Campina Grande, 2017.

SMANHOTTO, A.; SOUSA, A. de P.; SAMPAIO, S. C.; NÓBREGA, L. H. P.; PRIOR, M. Cobre e zinco no material percolado e no solo com a aplicação de água residuária de suinocultura em solo cultivado com soja. Engenharia Agrícola, v. 30, n. 2, p. 346-357, 2010. https://doi.org/10.1590/S0100-69162010000200017

SNYMAN, H. A. A greenhouse study on root dynamics of cactus pears, Opuntia ficus-indica and Opuntia robusta. Journal of Arid Environments, v. 65, n. 4, p. 529-542, 2006. https://doi.org/10.1016/j.jaridenv.2005.10.004

TAIZ, L.; ZEIGER, E.; MOLLER, I. M.; MURPHY, A. Fisiologia e desenvolvimento vegetal. 6. ed. Porto Alegre: Artmed, 2017. 888 p.

WILCOX, C. S.; FERGUSON, J. W.; FERNANDEZ, G. C. J.; NOWAK, R. S. Fine root growth dynamics of four Mojave Desert shrubs as related to soil moisture and microsite. Journal of Arid Environments, v. 56, n. 1, p. 129-148, 2004. https://doi.org/10.1016/S01401963(02)00324-5

XIA, C.; CHRISTENSEN, M. J.; ZHANG, X.; NAN, Z. Effect of Epichloë gansuensis endophyte and transgenerational effects on the water use efficiency, nutrient and biomass accumulation of Achnatherum inebrians under soil water deficit. Plant and Soil, v. 424, n. 1-2, p. 555-571, 2018. https://doi.org/10.1007/s11104-018-3561-5

ZHOU, Y.; BASTIDA, F.; ZHOU, B.; SUN, Y.; GU, T.; LI, S.; LI, Y. Soil fertility and crop production are fostered by micro-nano bubble irrigation with associated changes in soil bacterial community. Soil Biology and Biochemistry, v. 141, p. 107663, 2020. https://doi.org/10.1016/j.soilbio.2019.107663 